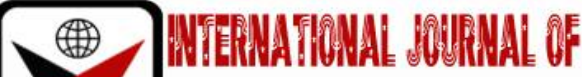

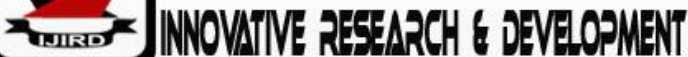

ISSN 2278 - 0211 (Online)

\section{Recent Issues in Human Rights and Injurious Moral and Religious Values in African Societies: The Nigerian Experience}

\author{
Dr. Joshua Igonoh \\ Senior Lecturer, Law College, Salem University, Lokoja, Kogi State, Nigeria
}

\begin{abstract}
:
No doubt, human right in contemporary world has developed far beyond the original perception of the founding fathers of the concept after the Second World War. Such areas include right of women and children including scientific and social issues like homosexuality, female circumcision otherwise referred to as Female Genital Mutilation (FGM), Genetic Engineering, In Vitro Fertilization and Blood Transfusion. These issues raise a lot of religious, moral and cultural value questions in Nigeria and several African Countries that could drive a huge wedge in the path of effective administration of human right laws in Nigeria. Using the issue of where to draw a line between law, morality and religion and how far law may be employed towards enforcement of certain moral and religious tenets, this paper explored the possibility of importing the concept of Bioethics into administration of the law on human rights to give human right outfit such human face that could enhance its impact in the grossly cultural Nigerian communities.
\end{abstract}

Keywords: Recent Issues, Human Rights, Injurious Values and Nigerian Experience

\section{Introduction}

One area that has attracted serious philosophical exploration in recent times is where to draw a line between law, morality and religion and how to handle emerging issues in jurisprudence in that behalf because of the interconnectivity between these three concepts. This need has become more emphatic because of the place of the distinction between the trio, in determining the extent to which law must be used to enforce morality and religion; and where their parting line could be drawn. It is imperative to acknowledge the fact that areas where their respective values seem to contradict the tenets of each other are numerous. Accordingly, where to draw a dividing line between values which each society considers as moral or religious values that should be protected and those that should be retained in the interest of the rule of law is of paramount importance to this paper. In an era where the world continues to search for alternative to existing systems that fail to meet social challenges, the quest to identify reasons for differences between what the law says and what the people think on the one hand, and how to contain such situation on the other, has in recent times, become central to the drive in African Jurisprudence to find relevance in a world that is fast shifting the values upon which each people's perception of their domestic laws and even the domesticated international laws are premised.

Looking at this issue from the perspective of female circumcision as a core-value in some African communities including Nigeria; genetic engineering and In Vitro Fertilization (IVF) as rights to acquire and express knowledge; and blood transfusion as a right to be protected against torture and pain, including the issue of abortion which is a right to do whatever a person likes with herself as long as he or she does not affect rights of others, will help draw a helpful conclusion in this behalf. In the end, Bioethics will be explored to balance societal values on this subject with the human rights ideals, in the circumstances of the Nigerian situation. For the purpose of clarity, each of the concepts is taken one after the other and where possible, they are taken together.

\section{Female Circumcision}

The issue of female circumcision otherwise referred to as "Female GenitalMutilation" involving the severance of varying parts of female genitals, cuts across various continents and countries of the world, with Nigeria accounting for about $25 \%$ of the estimated $115-130$ million circumcised women, worldwide. ${ }^{1}$ In Nigeria, like other countries of the world, female circumcision is categorized into four main classes that are usually simply referred to as types one, two, three and four. ${ }^{2}$ While type one which is less severe involves the removal of the prepuce or the hood of the clitoris, type two involves removal of the labia minora. This category is less severe than type three involving the removal of the clitoris, the labia minora and the medial part of it so that the vaginal orifice is stitched up, leaving a hardly visible space, only for urine and

T.C. Okeke, U.S.B. Anyaeline, and C.C.K. Ezenyeaku, 'An overview of Female Genital Mutilation in Nigeria' $<$ www.ncbi.nlmnih.gov/pmc/articles/pmc35007121> accessed on $20^{\text {th }}$ September, 2015. 
menstrual flow. The fourth type involves all the procedures in types one, two, and three, including introduction of all forms of toxic substances in the name of checking excessive disposition towards promiscuity. ${ }^{3}$

In the communities where this practice is prevalent, it is usually associated with the need to ensure virginity and curb promiscuity, to protect female modesty and chastity and as a traditional measure that initiates young girls into the kind of womanhood approved by the gods, to ensure fertility. ${ }^{4}$ In some communities, this practice has been associated with advantages that include chastity, moral purity, family honour from any form of promiscuity and modification of sexuality of women, increase in sexual pleasure, fertility and matrimonial opportunities. ${ }^{5}$

The prevalence of this practice over the years has been ensured by support of pivotal opinion leaders of their respective communities like mothers, women, age groups, grandmothers and community leaders thus compelling parents to offer their daughters for the ritual to avoid ostracization. ${ }^{6}$ However, for a long time, several Organizations, including UNICEF and of late, the World Health Organization have engaged in campaign against this practice, mainly on medical grounds ranging from shock, pain, hemorrhage, resulting in death, infection, acute urinary retention, trauma, damage to the urethra, chronic pelvic infection, acquired gynatresia resulting in hemotocolpos, vulval adhesion, dysmenorrhea, retention cysts, sexual difficulties with anorgasmia and several proven claims to health disabilities resulting from the procedure. ${ }^{7}$

But the emerging development of modern human rights has introduced another dimension into the crusade against female circumcision that has earned this cultural ritual, the acrimonious christening of Female Genital Mutilation. ${ }^{8}$ Thus, this long standing traditional practice, cutting across several Continents of the world is now regarded as a human rights violation in form of 'extreme form of discrimination against women... violation of a person's rights to health, security and physical integrity,... freedom from torture and cruel, inhuman or degrading treatment' and the right to life when the procedure results in death. ${ }^{9}$ Recently, United States Tribunal on Asylum ruled that female circumcision violated women's human rights, describing it as "cruel, painful and dangerous procedure" and stressing the need for a more forthright measure against the practice..$^{10}$

Available data shows that of the over two hundred million of the Nigerian population, with women constituting $52 \%$ of the total population, about $25 \%$ of the women population are circumcised thus showing extent of entrenchment of the practice. Of this figure, only $37 \%$ of the circumcised women detest the practice thus showing level of public support despite international outcry against the practice and the medical risk said to attend to it.Indeed, as far back as $2008^{11}$, Nigeria Demographic and Health Surveys (NDHS) showed that the prevalence of the practice amongst various ethnic groups remained virtually unchanged despite Federal and State government policies against the practice, resulting from lack of implementation-strategy on Government policies ${ }^{12}$. Studies by Osifo ${ }^{13}$, on Female Genital Mutilation among Edo people indicate that even parents brought their own daughters for circumcision, and that of the one hundredparents interviewed sixty-seven of them believed strongly in female genital circumcision on religious and cultural grounds.

AlthoughIslamic Scholars are divided on the connectivity of this practice to Islamic religion and on the authenticity of claim of the practice to Sunna source, available evidence tend to show that female genital circumcision was more of a strongly entrenched cultural practice amongst the Arabs before the Prophet caught the revelation of Islam, thus explaining

30.0. Ogaga, 'Dangers in Female Circumcision-the Nigerian Situation (848 views)' <www.nairaland.co/1530847/dangers-female-circumcision-thhenigerian-situation $>$.

4 These reasons cover its prevalence in the South-South where over $77 \%$ of adult women have been initiated; $68 \%$ in the South East and $65 \%$ in the South West with minimal but dangerous process in the North. See Okeke, etal, op.cit at 6.

5 Okeke, op.cit., at 21; Yerima, T.F., 'Combating the Menace of Female Genital Mutilation Within the Context of Criminal Law in Nigeria' Nigerian Law Journal (2016) vol 19, No.2, p.307

6 M.M.McSwenery, 'Female Circumcision: A Risk Factor in Post-Partum Hemorrhage' <www.hindura.com/journals/oogi/2013/496564/> accessed on 2009-2015. When Kenyan government passed a law criminalizing the practice in the year 2000, the Masssai tribe protested the ban on the ground that it breached their core values; Yerima, op.cit., at 311.

${ }^{7}$ Ibid; Yerima, T.F., 'Eradicating the practice of Female Circumcision/Female Genital Mutilation in Nigeria within the context of human rights' Journal of Law, Policy and Globalization (2014) Vol.14 at 129.

${ }^{8}$ World Health Assembly Itinary <afro.who.int/.../nigeriia/.../7651> accessed on 20-09-2015; Okeke, op.cit., at 27; Yerima, op.cit., at 309-310

$\underline{9}$ M. Jpeg, 'Female Genital Mutilation' <www.who.int/mediacentre/factsheets/.../e...> accessed on 7-07-2015.See also Ahmed, I.D; 'Female Genital Mutilation: An Islamic Perspective' <www.minaret.org/fgm-pamphlet.html $>$ accessed on 07-07-2015.

\section{Jpeg, op.cit., at 7 .}

11 Ibid.

12 Some of the policies include establishment of a multisectoral technical working committee on Harmful Traditional Practices (HTP); Studies and National Surveys on HTPs; Launching of Regional plan of action and formulation of National Policy plans, and the like. The practice in Nigeria is being confronted by joint effort of UNICEF, Federation of International Obstetrics and Gynecology (FIGO), African Union, the Economic Commission for Africa (ECA) and several Women Organizations; Okeke, op.cit. See Nigeria Demographic and Health Surveys (NDHS) Report on Female Circumcision in 2008. <unicef.org/Nigeria/ng_publication> accessed on 26-05-2016; A.M. Zegriff, 'Prevalence of Female Genital Mutilation (FGM)' <www.ecoi.net/locallink/144821/259833-de.html> accessed on 20-09-2015.

$\underline{13}$ A Consultant with University of Benin Teaching Hospital and President, Medical Women Association of Nigeria, Edo State Chapter who has been at the forefront of advocacy and enlightenment on the dangers of female circumcision. www.ncbi.nim.nih.gov/pubmed/20687262 accessed on 23-11-16.See also Jpeg, op.cit. 
the carry-over of the practice into Islam by some Islamic Scholars.All the same, the carry-over effect has been so longstanding and strong that in some Islamic countries like Egypt, Libya, Syria, Yemen and the Sudanese, over $90 \%$ of the women are said to be circumcised ${ }^{14}$. Indeed, in some states of Northern Nigeria, category 4 of the practice is said to be rampant on the claim that it helps curb impurity and promiscuity amongst the female faithfuls ${ }^{15}$.

From this rundown, it is obvious that the practice is such an entrenched moral and religious value in communities where it has been employed over the years but in view of the grim revelation of its risk-implication to health, the question is, where a core-cultural value contradicts core human rights like right to health and right to life, how far must such a cultural value be accommodated? In other words, does acceptance of a core-value by the society erode the rights of its victims to be protected against its pains and health-implications? Or, should the rule of human rights law be allowed to erode entrenched moral, religious and cultural values of a people where such values may be considered as injurious to the society? Answer to these all-important questions, constitute the basis for determining extent to which core-values of each people should influence application of any law, including human rights law, in each society; or extent to which human rights ideals must be allowed to traverse the people's moral and religious core values. This is why the need to employ the principles of bioethics is recommended in this paper, as a measure towards resolving the differences in a manner that the ends of justice may not be defeated, after all.

The question therefore is, what is bioethics? It is an aspect of ethics that explores ethical questions on how to take decisions about behaviour and policy questions that governments, organizations and communities must face when they consider how best to exercise preference in competing situations. ${ }^{16}$ It seeks to figure out what should be done or the best course of action that should be adopted in some complex situations ${ }^{17}$. The difference between ethical science and bioethics is that while the former seeks to know how to contain a particular situation but the later, bioethics is much more interested in the basis for the decision. ${ }^{18}$

Why it is imperative to discuss bioethics in this paper is because it is not as close-ended as the law, thus explaining why something can be illegal and yet ethical although something can be unethical andyet, not illegal because while law sets standard, like the law on human rights, ethics admonishes virtue. ${ }^{19}$ This is why in ethics, the primary focus include, respect for persons, minimizing harm in the effort to maximize benefits and then, fairness. ${ }^{20}$ This explains why ethical questions usually arise when individuals or group interests are under threat of harm, disrespect and unfair disadvantage; to identify all available options and considering implication of each option. By such measure, bioethics would help to bridge the gap that is created by the impression that universal human right is individual-centered at the expense of collective interest, which is the bane of African jurisprudence and the essence of the concept of relativism.

It must be noted that the entrenchment of this practice in Nigeria resulted in the Nation joining the World Health Assembly, in 1994 to set in motion various measures for prohibition and possible elimination of female circumcision. ${ }^{21}$ Following this lead, several States in Nigeria have taken several failed measures and passed laws prohibiting this practice, without any visible result, though. ${ }^{22}$ Reasons often proffered for ineffectiveness of State ban on this practice range from its long entrenchment; grassroot support and deep-seated socio-cultural African traditional belief in the efficacy of what the practice stands for. ${ }^{23}$

Bemoaning ineffectiveness of the law on this subject in Edo State of Nigeria, a scholar said because of its religious and cultural undertone, this practice has been difficult to eradicate despite Western education because of its entrenchment within the societies where this practice has been in vogue for so long. ${ }^{24}$ This, according to the scholar accounts for why the practice seems to be assuming a wilder posture underground now, rather than being stemmed by official opposition in form of policies and laws. ${ }^{25}$

Asif to respond to the resilience of this practice and international pressure to wield a stronger attack on the practice, the Nigerian Government, in 2015 passed another law proscribing female circumcision, amongst other practices, categorized as violent acts against persons ${ }^{26}$. Looking at the provisions of this Act, it is apparent that it may suffer the same fate that various State laws banning the practice suffered in the past because, the Act does not include any working plan

\footnotetext{
${ }^{14}$ Ibid. See Yerima., 'Eradicating... Circumscision' op.cit at 131 canvassing female circumcision as cultural right

${ }^{15}$ Ibid, Jpeg, op.cit.

16K.S. Thean, 'What is Bioethics: Defining Ethics and Bioethics' <mstrzel.eletel.p.lodz.pl/mstrzel/> accessed on 25-05-2016

17 Ibid.

${ }^{18}$ D.N.Irvin, 'What is Bioethics?' <uffl.org/vol10/irvin10.pdf> accessed on 25-05-2016

19 Ibid.

${ }^{20}$ Ibid.

${ }^{21} \mathrm{Jpeg}$, op.cit at 7; Yerima TF; 'Eradicating....Circumcision' op.cit at 131.
}

22 They include Bayelsa State by its 'State Female Genital Mutilation Law, 2000'; Cross River State by its 'Law to Prohibit Girl-Child Marriages and Female Circumcision or Genital Mutilation Law, No.2, 2000'; Ekiti State by its 'Ekiti State Female Circumcision (Prohibition) Law, cap E13, No.6, 2002'; and Ebonyi State by its 'Abolition of Harmful Traditional Practices Against Women and Children Law (cap 209) 0f 2009'; Yerima op.cit., at 316; The Guardian Newspaper, 'Nigeria's Female Genital Mutilation Ban is Important, Precedency says as the outgoing President Goodluck Jonathan bans FGM in one of final acts'<www.theguardian.com/ society/2015/may/29outlawing-fgm-nigeria-hugely-important-president-say-campainers $>$ accessed on 20 -09-2015.

${ }^{23}$ P. Ochoga, 'Female Circumcision in Nigeria' <Nigeria.shafaqua.com/EN/NG/1007757> accessed on 12-04-2016.

${ }^{24}$ Ibid; Yerima., 'Combating the Menace of FGM' op.cit at 308 where learned author traced connectivity of this practice to 'cultural norms and traditions'

26 Violence Against Persons (Prohibition) Act, 2015, Section 5. See the Guardian Newspaper, 'Nigeria's Female Genital Mutilation Ban is Important, Precedency says as the outgoing President Goodluck Jonathan bans FGM in one of final acts'<www.theguardian.com/ society/2015/may/29outlawingfgm-nigeria-hugely-important-president-say-campainers> accessed on 20-09-2015. 
for implementation. Such plan should include the constitution of a broad-based committee as was done in Ekiti State of Nigeria, to educate and re-orientate the people against the odds and health-risk of the practice, and where necessary, engage the services of well-trained grassroot campaigners to hold regular community-based workshops that could debunk the people's moral and religious notion on the practice. Such measure imports the necessity for sociological philosophy for effective implementation of the laws on this subject, in the respective States because to propose otherwise tantamount not only to distancing African jurisprudence from world trend but creating irreconcilable chasm between law and the people's notion of values.

While it is conceded on the principles of bioethics that, for all the health risks involved, the States and Federal Governments flexing of muscles is imperative to curb the excesses of this traditional practice especially regarding the third and fourth types of female genital circumcision, the question is whether any law can address the issue without putting into proper perspective the cultural beliefs and values of the people? Indeed, it is obvious that answer to this resilient practice does not lie in legislation because of the extent of its entrenchment. This is why it is suggested that more resources be invested towards advocacy and enlightenment to re-orientate the people's values, whether religious, moral, sociological or cultural. Such view held by several scholars is because emphasis on legislation and punishment could be counterproductive, forcing the practice underground, resulting in victims avoiding medical care to avoid criminal prosecution of their parents ${ }^{27}$.

In the end, the bottom line of this issue is that no matter how imperative societal values are, towards ensuring effective rule of law, they must not be allowed to override the essence of the society itself. It is in such situation societal core-values must submit to the rule of law, including human rights law. This is where the issue of bioethics becomes inevitable, to examine and balance the moral and religious benefits of this practice, against the health-risk involved.

\section{Genetic Engineering}

The issue of Genetic Engineering is a process by which individual Deoxyribo nucleic Acid (DNA-fragments) are cross-matched with other genetic materials by which genres are made to replicate themselves and then introduced to host cells of the scientific exercise, to produce clones that are harvested and used for several purposes, including medical investigation of gene structure, for the control of genetic disease, hormone and protein synthesis and animal research ${ }^{28}$.

The issue of any connection between morality and religion, and the laws permitting genetic engineering has been a divisive one since 1964 when the World Medical Association made the Helsinki Declaration on it, first prohibiting it and subsequent variation of such declaration by American Medical Association, permitting it for research purposes only ${ }^{29}$. It is in line with such variation that the Supreme Court of United States ruled that it could be employed as an economic incentive for companies to develop genetically engineered products ${ }^{30}$. Since then, several States in the US have passed laws strictly regulating, curbing and in some cases prohibiting the spread of genetically engineered products in open market ${ }^{31}$. Such regulations became imperative, more so, that researchers resorted to using it beyond therapeutic purposes and as a means of combating the HIV virus and then, to cloning of a sheep in 1997 and later, cows, pigs, monkeys, cats and some endangered animals ${ }^{32}$. This they do by replacing the nucleus egg-cell of their subject with the nucleus of the intended cloned subject thus creating an altogether different personality ${ }^{33}$. Indeed, since November 2001 when scientists first successfully inserted the DNA of one cell into another human egg with wild resultant replication, the issue of human cloning has been generating a lot of scientific, moral and religious controversies over the complexities that would result from such ventures ${ }^{34}$.

The moral and religious questions border a lot on human attempt to co-create with God but more importantly, on the manipulation of a totally different personality arising out of cloning, similar to the result that forms the basis of church opposition to In Vitro Fertilization. The main fear of anti-geneticists is that a gene can be manipulated to attract some unwanted disposition like anger, melancholy, schizophrenia or selfishness, a conclusion that geneticists deny with equal force $^{35}$. As Paloma argued, there is no scientific proof that passion is an issue for the gene to justify entertainment of fear of transfer but such reasoning amounts to challenging the very basis for DNA which provides that the totality of what is contained in the YX and XX cells of a man or woman, are identifiable in their children ${ }^{36}$.

But the main concern of this paper lies in the fact that manipulation of genes could produce humans with the same DNA result. The question then is, when one of these products of genetic manipulation commits an offence, how does the

\footnotetext{
27 Yerima, op.cit at 331.

28 S. Thalhammer, etal 'Genetic engineering: The Human Manipulation of the Genetic Material of a cell' <www.yourge nome.org/facts/what-is-genetics> accessed on 21-05-2016; A. Palomo-Lamarca; 'Is Genetics a Matter of Faith?' <http://serbal.pritic.mec.es/AparteRei/> accessed on 15-05-2016.

${ }^{29}$ Ibid.

${ }^{30}$ Diamond v Chakrabarty, 447 U.S.303, 100 S.ct 2204.

31 Such States include Minnisota, Oklahoma, North Carolina and Several others <law.jrank.org/pages /7121/genetic-engineering> accessed on 26-052016.

32 Ian Wilmot, a Scot cloned a sheep nicknamed 'Dolly' in $1997<$ prezi.com/.../genetic-cloning> accessed on 21-05-2016.

33 Thalhammer, op.cit at 7 .

${ }^{34}$ Ibid.

35 Palomo, op.cit 
law fix its identity? With such resemblance, how do parties to a transaction determine the personality involved when the DNA shows that the personalities in contest are of common origin? This goes beyond moral and religious question of putting the innocent in jeopardy, to a more complex dilemma for the rule of law if the issue of genetic engineering is not regulated within special circumstances of each environment; especially in several complex, crime-prone African societies, including situations as exist in Nigeria. To undertake such exercise, the ideals of bioethics should be explored so that the circumstance surrounding each case should be treated in isolation, for a more functional result. It may be necessary to discuss IVF before delving into the implication of bioethics for genetic engineering in this research, to avoid duplicity especially because of the similarity of the workings of these two concepts.

In Vitro Fertilization (IVF) and Blood Transfusion

It appears that the complexity of conflict between scientific discovery, human rights development, moral and religious values lies more in IVF where the sperm from a man, and an egg harvested from a woman combine to create a new but unique genetic human being ${ }^{37}$. After the embryos are created, the Doctor selects the number of his choice for implantation into the mother's womb or incubating tube, with the hope of at least, one surviving, to be born some nine months later ${ }^{38}$. The Catholic Church in particular has taken exception to this procedure on two grounds ${ }^{39}$. Firstly, that sex being an act of love by which God could choose to bring forth new human life, made in his image and likeness, must not be abused by a procedure that down-plays its essence; and secondly, that this procedure amounts to violating the child's integrity as a human being, with an immoral soul from the moment of conception, as it deprives the child the right to be born of a father and a mother known to him and which deprives the spouses the right to become parents only through mutual expression of love ${ }^{40}$.

Butit appears that the real moral question on IVF lies in the determination of when "life" in the real definition of the word can be said to be imparted upon the embryo, to enable one allude human status to it. This question becomes imperative having regards to the fact that early in the pregnancy, the couple who are beneficiaries of an IVF baby are given the option of selecting the baby of their choice, in case of tube procedure, while the rest are killed to enhance survival of the selected one ${ }^{41}$.

If the consensus is that life exists in the embryo at the time of their selective destruction, it amounts to a breach of core religious value of "thou shall not kill" 42 . But it must not be forgotten that under laws of various jurisdictions including Nigerian Constitution, there are conditions for derogating from the right to life thus suggesting that this right, although primary, is not absolute. Therefore, in the circumstance of barrenness resulting from infertility or some other biological deficiencies resulting howsoever, a procedure that removes the stigma and unhappiness of barrenness must not be sacrificed on the altar of religious values that protect embryos that would not have come into existence without initiation of the same procedure, in the first place. Balancing this kind of conclusion against other competing interests contribute to the reason bioethics has been imported into this work.

In any case, in exploring ideals of bioethics, as an attempt to plug the loopholes of sociological philosophy, which is the relevant philosophy to the subject of this paper, it is humbly submitted that except in obvious cases where the issue of genetic engineering and IVF are deliberately abused, it may be too early to dump them for some subjective moral or religious values, until the world comes to terms with their contributions to social upliftment. This is the perspective from which we should see the perception of Jehovah's Witness Christian Sect on the issue of blood transfusion, as a breach of their core-values, arising from their peculiar views on some portions of the bible ${ }^{43}$. This is because, interpretation of scriptures is by revelation which may vary from one situation to the other, especially where the issues involved are not clear-cut as is the case of the scriptures which this Christian sect relies upon, which forbid eating flesh with blood, without any serious suggestion that they point to blood transfusion.

Such misunderstanding informed a religious tribunal's condemnation of Galileo in 1680 because of a simple, plain sentence that the earth moves around the sun ${ }^{44}$. It was for similar reason the church condemned Charles Darwin for his finding that the earth is round, all because of limited under standing of what the scriptures actually mean, and because of limited scientific understanding at the time ${ }^{45}$. It is for this reason this work counsels that whatever premium must be placed on core religious values against any scientific discovery that seems to better the life of the society,must be with uttermost caution. In the end, this is another situation, like the IVF, where the issue of bioethics must be employed as a

$\underline{37}$ T. Kenny, 'Begotten not Made: The Church's Stance on IVF'<www.popepaulvi.com/pdf/.../fcccol.pdf> accessed on 15-05-2016.

${ }^{38}$ C. Marcia, 'Local Babies, Global Science: Gender, Religion and In Vitro Fertilization' <communitybaby centre.co.uk/post/a71.../>accessed on 15-05-2016. Against the precept of Holy Bible, Exodus Chapter 20:13; Sanity and Social Justice. 'Catechism of the Catholic Church on Fertility Treatment' $<$ sanityandsocial justice.net/\%3ftage\%3..>accessed on 15-05-2016

${ }^{39}$ Marcia, op.cit.

40 Ibid.

41 Kenny, op.cit at 2.

42 Holy Bible, Genesis Chapter 9:4; Leviticus Chapter 17:10\&14; Deuteronomy Chapter 12:23 and Acts Chapter 15:28 \&29 which deal with interconnectivity between blood and life.

43 D. Norfolk, 'Handbook of Transfusion Medicine' $5^{\text {th }}$ ed. at www.transfusionguidelines.org/trans... accessed on 23-11-16.

44 W.T. Doug-Linder, 'The Trial of Galileo' <law2.umkc.edu/.../galileoaccount.html>accessed on 15-05-2016.

${ }^{45}$ M. Robert, 'Charles Darwin and the Church' < churchsociety.org/docs/churchman/10../>accessed on 15-05-2016. 
measure to determine the scale or indices upon which to balance the competing moral and religious values or concepts, against human rights ideals or scientific discoveries.

\section{Conclusion and Recommendation}

Using recent human right ideals, including Female circumcision, Genetic Engineering, In vitro Fertilization (IVF) and Blood Transfusion as case study, this paper has explored possible dividing line between the tenets of human rights and some moral and religious African values, reckoned as injurious to contemporary human right ideals. The paper takes a position that outright enforcement or exclusion of some recent human right developments may be counter-productive, driving African societies farther away from the real import of human right ideals. Thus, the paper recommends a more pro-active role for sociological philosophy and the concept of Bioethics as a measure to give human right a more cordial human face for greater impact within African legal system, and the Nigerian society in particular.

\section{References}

i. Ahmed, I.D; 'Female Genital Mutilation: An Islamic Perspective' <www.minaret.org/fgm-pamphlet.html> accessed on 07-07-2015.

ii. Doug-Linder, W.T., 'The Trial of Galileo' <law2.umkc.edu/.../galileoaccount.html>accessed on 15-05-2016.

iii. Ian Wilmot, 'Genetic Cloaning'<prezi.com/.../genetic-cloning> accessed on 21-05-2016.

iv. Irvin, D.N., 'What is Bioethics?' <uffl.org/vol10/irvin10.pdf> accessed on 25-05-2016

v. Jpeg, M., 'Female Genital Mutilation' <www.who.int/mediacentre/factsheets/.../e...> accessed on 7-07-2015.

vi. Kenny,T., 'Begotten not Made: The Church's Stance on IVF'<www.popepaulvi.com/pdf/... ./fcccol.pdf $>$ accessed on 15-05-2016.

vii. Marcia, C., 'Local Babies, Global Science: Gender, Religion and In Vitro Fertilization' <community baby centre.co.uk/post/a71.../>accessed on 15-05-2016.

viii. McSwenery, M.M., 'Female Circumcision: A Risk Factor in Post-Partum Hemorrhage' $<$ www.hindura.com/journals/oogi/2013/496564/> accessed on 20-09-2015.

ix. $\quad$ Norfolk, D., 'Handbook of Transfusion Medicine' $5^{\text {th }}$ ed. at www.transfusionguidelines.org/trans... accessed on 2311-16

X. Ochoga, P., 'Female Circumcision in Nigeria' <Nigeria.shafaqua.com/EN/NG/1007757> accessed on 12-04-2016.

xi. Ogaga, O.0., 'Dangers in Female Circumcision-the Nigerian Situation (848 views)' $<$ www.nairaland.co/1530847/dangers-female-circumcision-thhe-nigerian-situation>.

xii. Okeke, T.C., Anyaeline, U.S.B., and Ezenyeaku , C.C.K .,'An overview of Female Genital Mutilation in Nigeria' $<$ www.ncbi.nlmnih.gov/pmc/articles/pmc35007121> accessed on 20 ${ }^{\text {th }}$ September, 2015.

xiii. Palomo-Lamarca, A; 'Is Genetics a Matter of Faith?' <http://serbal.pritic.mec.es/AparteRei/> accessed on 15-052016.

xiv. $\quad$ Robert, M., 'Charles Darwin and the Church'<churchsociety.org/docs/churchman/10../>accessed on 15-05-2016.

xv. Thalhammer, S., etal 'Genetic engineering: The Human Manipulation of the Genetic Material of a cell' <www.yourge nome.org/facts/what-is-genetics > accessed on 21-05-2016.

xvi. K.S. Thean, 'What is Bioethics: Defining Ethics and Bioethics' <mstrzel.eletel.p.lodz.pl/mstrzel/> accessed on 25-052016

xvii. Zegriff A.M. 'Prevalence of Female Genital Mutilation (FGM)' <www.ecoi.net/local-link/144821/259833-de.html> accessed on 20-09-2015.

xviii. Yerima, T.F., 'Combating the Menace of Female Genital Mutilation Within the Context of Criminal Law in Nigeria' Nigerian Law Journal (2016) vol 19, No.2, p.307.

xix. Yerima, T.F., 'Eradicating the practice of Female Circumcision/Female Genital Mutilation in Nigeria within the context of human rights' Journal of Law, Policy and Globalization (2014) Vol.14 at 129. 